PhD-AnMeldelser

\section{Mia Muurimäki. Nykytaiteen Politiikka Museokontekstissa [Contemporary Art and Politics in the Museum Context]. Ph.D. thesis, Helsinki: Aalto University, 2013.}

Mia Muurimäki's Ph.D. thesis Nykytaiteen politiikka museokontekstissa [Contemporary Art and Politics in the Museum Context] deals with the politics of encountering contemporary art in the museum context. As a case study, she has chosen The Kiasma Museum of Contemporary Art in Helsinki, which was founded in 1998. The empirical data has been collected in connection with three exhibitions: Landscape (2007), Wind from the East (2007), and ARS11 (2011).

The author is interested in the political potential of contemporary art from the standpoint of strengthening democracy. She describes her research as normative, as openly committed to certain values and goals. Muurimäki understands the museum of contemporary art as a place and an actor that is able to support the birth of "the political", which is a precondition for maintaining democracy. She considers this as a way for museums to increase their social effectiveness, which is nowadays often required of them in return for public funding.

In the forward-looking applied section, Muurimäki discusses the possibilities of including ways to advance the implementation of the political potential of contemporary art, mainly different practices of interaction and participation, into the digital strategies of museums. The work is topical also in this respect.

Muurimäki denotes the key questions of her research as follows (p. 13):
1. What is the politicality in contemporary art displayed in a publicly funded museum of contemporary art?

2. What kind of political experiences, if any, do the objects of contemporary art produce within the museum environment?

3. How could the understanding of the political in contemporary art be utilised in developing museum work, especially in relation to the development of digitalisation?

\section{TheORETICAL MODEL OF THE POLITICAL}

The work could be described generally as interdisciplinary, diverse, and wide-ranging. The theoretical background of the research ranges from sociology and political philosophy to museology and design research. It can also be connected to the tradition of art sociological reception studies.

Muurimäki builds on the theories of three eminent sociologists of the political and the relationship of their views to (contemporary) art. Chantal Mouffe, Jacques Rancière, and Niklas Luhmann have differing approaches and objects of interest, but in their conceptualisation of the political, they all break away from everyday patterns of thinking. In addition to these three theorists, Bruno Latour is important to Muurimäki, and Michel Foucault also plays a role in her work. The museological aspect of the thesis relies especially on Nina Simon's thought on the participatory museum and museum 2.0.

In analysing Mouffe's, Rancière's, and Luhmann's conceptions of the political, Muurimäki utilises the structuralist semiotics of A. J. Greimas. In her hands each conception is moulded as part of Latour's larger, fivephase model of the political. It is a "circular process in which new things change our ways of conception, produce collectives that 
138 further conflicting goals, become objects of institutional control and normalising practices, whence they can eventually be reformed as new things for the process" (p. 226). The result is a decidedly elegant "depiction of the life cycle of different things within the political" (p. 15).

The candidate recounts having chosen the specific conceptions of the political, expecting them to help delimit the amount of political utterances in the empirical data. Another criterion has been that "working with the theory feels somehow promising". The hope was "to produce inspiring analyses of the many dimensions of the politics of art reception". The candidate has succeeded admirably, and there should be no reason to launch an exegetical inquiry in order to find out how orthodox her reading of the difficult theories actually is.

\section{THINK-ALOUD AS A METHOD}

The various methods utilised in the research include reception and artefact studies. The author has collected four different types of data: 1) think-aloud recordings (single participants and pairs, $\mathrm{N}=28$ ); 2) thematic interviews (single participants and pairs); 3) photographic data collected from the ARS11 exhibition using the methods of visual ethnography; and 4) blog discussion regarding the ARS11 exhibition.

The candidate considers the methodical standpoint of her work to have affinity with artefact studies, because the objects of art in the museum context (exhibition) are seen as eliciting social and political speech. Muurimäki has adopted Bruno Latour's idea of seeing an object of art as an actor. The standpoint is particularly inspiring when the candidate suggests that we could think of the objects of art as welcoming the museum visitors and reading them. Objects compel us to bear them in our thoughts and discourses, and thereby expand themselves.

The collected data is abundant. The thinkaloud recordings from the museum tour form an especially original and rich whole. Through thinking aloud, the researcher has striven to reach the unmediated experience of art objects. A lot of work has been put in the planning, preparation, and implementation of data collection and analysis. This shows especially well that the candidate has nowhere chosen to take the path of least resistance but instead worked persistently and ambitiously.

Muurimäki succeeds in transforming her political framework into a brilliant tool for analysis, which opens up new perspectives to encountering both people and contemporary objects of art. She spots nuances astutely from the data, especially in the think-aloud recordings and thematic interviews. If anything, the methodological choice can be criticised for being too extensive. Such vast and manifold data may not have been necessary for the research: A meticulous analysis of the sole think-aloud data could have been enough. The photographic data and the blog discussions with the informants did not take the analysis any further. In addition, the blog discussion largely failed due to technical difficulties.

\section{THE PROCESS OF THE POLITICAL OR THE POLITICS OF ART}

The candidate succeeds brilliantly in her ambitious aim to present a comprehensive depiction of the phases of politics (although the end result is a bit heavy and mechanistic). Yet one can ask whether the depiction of the whole political process is either necessary or useful for the research. More broadly, it is sometimes difficult to tell whether the principal aim is to map experiences of the 
political in the museum context, or to try and refine theories of the political through the empirical data collected in the museum.

It would have been enough to restrict the analysis to the beginning of the political process, considering the candidate's dedication to the revival of democracy in a certain radical sense. It would have been fruitful to simply analyse the think-aloud data collected in Kiasma using just Mouffe's and Rancière's concepts of the political. This would have enabled taking into account the nuances of their thought, which were spoiled by the simplifying necessitated by the chosen processual model. Mouffe's conception of the political can be summarised with the term confrontation, whereas central to Rancière's conception are the emergence of the dispossessed and the changes in the distribution of the sensible, which can be described, roughly, as the emergence of new perceptual schemes and world views. Here the connection to Luhmann's conception of the function of art is evident.

Narrowing down the topic would have made it possible to focus on a close reading of the data using the theories of Mouffe and Rancière, thereby deepening the analysis of the politics of art. This would have enabled a more accurate analysis of the theme of identification, which is mentioned repeatedly in the theoretical part of the work but which does not get the role it deserves in the analysis of the data. An analysis of Luhmann's system of art (not politics!) would have complemented especially the Rancièrean reading. Close reading would have allowed the candidate to pay more attention to Mouffe's and Rancière's writings about the politics of contemporary art and compare them to her own findings.

Muurimäki mentions, in passing, Carol Duncan's (1995) thoughts about the museum as a liminal space. She could have considered in more detail the effects the detachment from everyday life has to the experience of the political in the museum. Then again, she could have analysed the extent to which the extension of the museum experience outside the museum walls, through for example social media, brings the experience closer to the everyday ways of thinking. This is after all what the author herself emphasises by demanding platforms that would enable the reflection of the museum experience even after the visit, possibly in dialogue with other visitors.

Fig. 1. The Model of the Political by Muurimäki (p. 237).

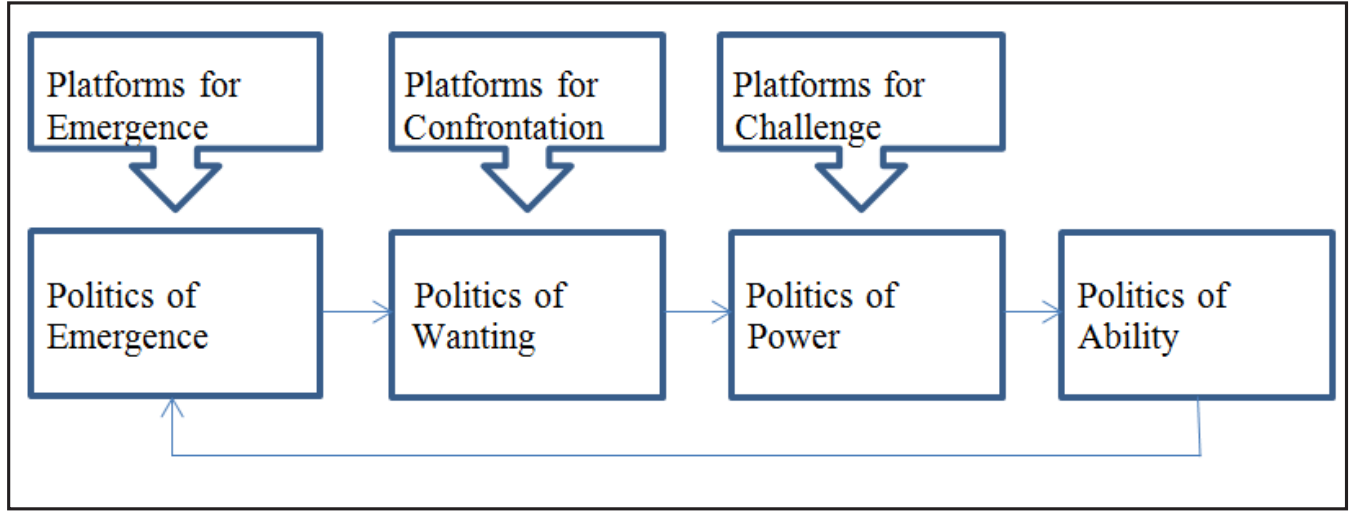




\section{Digital CONCEPTS}

The final part of the study focuses on design research and strives for implementing the conception of the political into practice. The aim is to develop such forms and models for the museum digital strategies that would further the realisation of the political potential of contemporary art, which again would function as the driving force for democracy.

The topic is exceedingly timely as the museum field is currently going through a rapid process of digitalisation and looking for new ways to open up their collections for online viewing and utilisation. The way the candidate deals with different participatory concepts and challenges participatory babble is praiseworthy. On closer inspection, the entire concept of participation turns out to be dubious as it implies that there exists a whole in which others are kindly asked to participate. All modes of participation do not automatically create communities and further democracy.

The political framework created by the candidate effectively highlights the pros and cons of existing digital concepts. The framework offers an organised view of the ways museums can participate in advancing democracy. The lack of such a view has been one of the biggest weaknesses in the digital solutions so far - in this sense the author is in line with Ari Häyrinen (2012) who also recently explored the problematics of opening up museum collections. A more thorough analysis of network activity is however needed before the move from the observations presented by the candidate to the full utilisation of the network society and social media can be made. In this respect, the advances of the work remain largely hypothetical.

The candidate seems to be frustrated with the quasi-action that is employed by many cultural institutions and has little to do with actual participation. An example of this is the way Kiasma utilises feedback forms and launches online comment platforms that are not monitored or seriously considered to provide data for developing the museum activity. This gives the impression that the museum is not actually interested in genuine, spontaneous interaction with the public but only with one that happens in terms set by the museum and the museum experts. According to Muurimäki, museums are nonchalant about the kinds of experiences they have produced. The political process is initiated and abandoned, in which case it is of no use to democracy.

The political model developed by the candidate highlights interesting thoughts for evaluating the aims behind and results produced by digital strategies, but on the whole the applied section of the work remains abstract. The focus is rather on assessing existing practices than developing altogether new ones. Surprisingly there is no discussion on museum pedagogy or education. Talking about the development of museum practices and the striving for "social effectiveness", it is difficult to ignore the already existing practice of museum pedagogy. It does not have to mean a situation that appears as hierarchical and asymmetrical from the standpoint of the visitor - a situation shirked by the candidate - for there are also varieties of museum pedagogy which start from the premise of radical democracy.

Throughout her work, Muurimäki emphasises the human need to be heard in the society. She encourages museums to record the experiences exhibits and exhibitions produce in the audience: "If we record experience, museum carries out more fully its important role as the mnemonic technique of our society, as a tool we use to outsource our understanding of what is meaningful, valuable, and insightful" (p. 301). 
At the core of the book is the insight that these experiences should be actively collected and the visitors should be encouraged to share their experiences, if art museums want to fulfill their political potential. Recording experiences using think-aloud is first and foremost a methodological choice that has also enabled the author to expose a small sample of the experiences produced by the exhibitions of contemporary art.

\section{TOWARDS SOCIAL EFFECTIVENESS}

Thematically the study is connected to contemporary museum political, and wider cultural political, discussions on participation, combined production, crowdsourcing, and online communality. A key question turns out to be how to get the museum visitors to feel like genuinely important actors. It is no longer a question of high cultural but societal participation. Participation is not only a universal human ideal but also one of the goals set in the current government platform.

Since one of the goals of the study is to increase the "social effectiveness" of museums, the examination should have been extended to cover official cultural policy that is echoed, through performance agreements, on the museum level. The problem is that neither the concept nor the background of social effectiveness is defined in the study. Analysing its history, the connection of the concept to the so-called new public management and neoliberal state control ideology, would have been revealed. In Finland the concept was implemented in public administration when the state financial reporting was renewed at the beginning of the 21 st century. There is an obvious paradox in how the candidate uncritically uses a concept the background of which Chantal Mouffe, for example, has openly condemned. Like the candidate states, Mouffe 141 thinks that the triumph of neoliberalism has rendered genuine politics impossible. New public management represents the "rational conduct" which Mouffe considers to be disastrous for democracy.

\section{Conclusions}

On the whole, Muurimäki's work is an inspiring horn of plenty. The author clearly does not want to restrict herself to a single standpoint or approach. Theoretical and methodological tools are borrowed from several disciplines and the amount of collected data is vast enough to warrant several studies. This diversity creates fresh ideas and interesting associations, many of which are only mentioned in passing or dealt with superficially. Let us hope that the author continues the analysis as a post doc researcher. The theoretical framework she has created for her doctoral thesis is robust enough to offer a good basis for a future career.

\section{LiTERATURE}

Duncan, Carol 1995. Civilizing Rituals. Inside Public Art Museums. London: Routledge.

Häyrinen, Ari 2012. Open Sourcing Digital Heritage: Digital Surrogates, Museums and Knowledge

Management in the Age of Open Networks.

Doctoral Diss. Thesis. Jyväskylä: University of Jyväskylä.

Sari Karttunen, The Foundation for Cultural Policy Research (Cupore) sari.karttunen@cupore.fi

Raine Koskimaa, University of Jyväskylä aine.koskimaa@jyu.fi 